\title{
Nurmikasvuston puna-apilapitoisuuden voi ennustaa kalsiumpitoisuudesta
}

\author{
Marketta Rinne ${ }^{1)}$ Arja Nykänen ${ }^{2)}$, Jukka Kemppainen ${ }^{3)}$, Laura Nyholm $^{4)}$ ja Juha Nousiainen ${ }^{4)}$ \\ ${ }^{1)}$ MTT, Kotieläintuotannon tutkimus, 31600 Jokioinen, etunimi.sukunimi@mtt.fi \\ ${ }^{2)}$ MTT, Kasvintuotannon tutkimus, Lönnrotinkatu 3, 50100 Mikkeli, etunimi.sukunimi@mtt.fi \\ ${ }^{3)}$ MTT, Palveluyksikkö, Kipinäntie 16, 88600 Sotkamo, etunimi.sukunimi@mtt.fi \\ 4)Valio Oy, Alkutuotanto, PL 10, 00039 Valio, etunimi.sukunimi@valio.fi
}

\section{Tiivistelmä}

Puna-apilan lisäämisellä rehunurmiseoksiin on monia hyviä puolia. Apilapitoisuuden vaihtelu nurmissa on kuitenkin suurta. Biologisen typensidonnan arvioimiseen, sadonkorjuun ajoittamiseen ja rehun syöntipotentiaalin ennustamiseen tarvitaan tietoa apilan osuudesta nurmikasvustossa.

Apilapitoisuuden määrittäminen botaanisella analyysillä on työlästä ja muilla menetelmillä kuten silmämääräisesti arvioiden varsin epätarkkaa. Puna-apilan kalsiumin (Ca) pitoisuus on huomattavasti korkeampi kuin nurmiheinien. Tämän tutkimuksen tarkoituksena oli selvittää, pystytäänkö nurmikasvuston puna-apilapitoisuus arvioimaan nurminäytteen Ca-pitoisuuden perusteella.

Puna-apilan ja nurmiheinien seoskasvustoja seurattiin MTT:n tutkimuspaikoilla Juvalla ja Sotkamossa vuosina 2004-2006. Lohkot olivat luomuviljelyssä. Näytteiden Ca-pitoisuus määritettiin Valio Oy:n laboratoriossa XRF-menetelmällä (X-ray fluorescence). Näytteiden kalsiumpitoisuuden ja puna-apilan osuuden yhteyttä tarkasteltiin regressioanalyysillä.

Yksinkertaisin yhtälö, jossa on mukana vain Ca-pitoisuus, toimi varsin hyvin. Selitysaste oli 0.800 ja mallin jäännösvaihtelu $10.7 \%$. Sen mukaan apilapitoisuus voitiin ennustaa yhtälöllä:

Apilan osuus nurmikasvuston kuiva-aineessa $(\%)=-3.1+4.22 \times$ Ca-pitoisuus (g(kg KA)

Sadon (1 vs. 2. sato) huomioiminen paransi ennustetarkkuutta. Myös maan Ca-pitoisuudella oli merkitsevä vaikutus. Jos nämä lähtötiedot ovat käytettävissä, niiden hyödyntäminen on suositeltavaa. Artturi-verkkopalvelun (www.mtt.fi/artturi) Laskurit-sivulla on käytettävissä laskuri, johon voi tallentaa näytteen lähtötiedot ja saada tulokseksi nurmikasvuston apilapitoisuuden.

Nurminäytteen Ca-pitoisuus määritetään Artturi-rehuanalyysin suppeassa kivennäisanalyysissä ja rehujen kivennäispitoisuudet ovat hyödyllisiä tietoja myös eläinten ruokinnan suunnittelussa, mikä puoltaa Ca-pitoisuuden käyttöä myös apilapitoisuuden arviointiin. Tämän tarkastelun perusteella yhteys vaikuttaa niin selvältä, että lähestymistapa on toimiva. Aineisto on kuitenkin pieni ja sisältää vain luomunurmista kerättyjä näytteitä. Muut tiedot mm. kasvuston kehitysvaiheesta (D-arvo) ja kemiallisesta koostumuksesta saattaisivat parantaa ennustetarkkuutta.

Ca:n ja puna-apilan pitoisuuksien yhteys määritettiin tässä nurmikasvustosta kerätyistä ja kuivatuista näytteistä. Menetelmää voi käyttää myös säilörehunäytteiden apilapitoisuuden arvioimiseen, koska Ca-pitoisuudessa ei ole odotettavissa muutoksia säilönnän aikana.

Asiasanat: puna-apila, kasvilajikoostumus, botaaninen koostumus, kivennäisaine, kalsium, Ca 


\section{Johdanto}

Puna-apilan lisäämisellä rehunurmiseoksiin on monia hyviä puolia. Apila on typpiomavarainen ja sen käyttö antaa joustoa rehunurmien korjuuaikaan. Apilapitoisen rehun syöntipotentiaali on suurempi kuin puhtaiden nurmiheinärehujen (Rinne ym. 2008), joten myös maitotuotos ja eläinten kasvunopeus potentiaalisesti lisääntyvät. Lisäksi apilan syötöllä on positiivinen vaikutus maidon rasvahappokoostumukseen ihmisravitsemuksen kannalta. Lehmien ravitsemuksen kannalta apilan $(\mathrm{Ca}+\mathrm{Mg}) / \mathrm{K}-$ ekvivalenttisuhde on nurmiheiniä parempi. Kesällä 2006 tehdyn viljelijäkyselyn mukaan kolmannes nautakarjatiloista käyttääkin puna-apilaa nurmiseoksissa (Pursiainen ym. 2007).

Apilapitoisuuden vaihtelu nurmissa on kuitenkin suurta. Tyypillisesti apilan pitoisuus on kesän ensimmäisessä niitossa pienempi kuin loppukesällä. Apilan pysyvyys nurmissa koetaan usein ongelmaksi, koska satovuosien karttuessa apilan pitoisuus usein pienenee (Nykänen ym. 2000). Vaihtelu on kuitenkin suurta johtuen mm. kasvuolosuhteista ja lajikkeiden ominaisuuksista (Hakala ja Yli-Mattila 2007). Käytetyn typpilannoituksen määrä vaikuttaa merkittävästi apilan osuuteen nurmissa. Nurmiheinien kilpailukyky kasvaa typpilannoitusta käytettäessä, jolloin apilan osuus kokonaissadosta jää pienemmäksi (Mela 2003).

Biologisen typensidonnan arvioimiseen, sadonkorjuun ajoittamiseen ja rehun syöntipotentiaalin ennustamiseen tarvitaan tietoa apilan osuudesta nurmikasvustossa. Luomuviljelyn typpitalous perustuu palkokasvien kykyyn sitoa juurinystyräbakteerien avulla ilman typpikaasua kasveille käyttökelpoiseen muotoon. Palkokasvipitoisissa nurmissa sidotun typen määrä ja sitä kautta ravinnetaseet voidaan arvioida kasvuston apilapitoisuuden perusteella (Nykänen 2007).

Korjuuaikapäätöstä tehtäessä on huomioitava eri kasvilajien osuus kasvustossa niiden erilaisen kehitysrytmin vuoksi. Puna-apilan sulavuus (D-arvo) laskee alkukesällä noin puolet hitaammin kuin nurmiheinien (Rinne ym. 2007). Apilapitoisen nurmen korjuu voidaan tehdä jonkun verran heinäkasvinurmia myöhemmin, mutta ajoituksessa on huomioitava myös apilan osuus nurmessa, sillä apila ei paranna seoksessa mukana olevien heinäkasvien sulavuutta. Apilan osuus säilörehuseoksessa vaikuttaa myös siihen, kuinka paljon lehmät pystyvät vapaasti tarjolla olevaa säilörehua syömään (Rinne ym. 2008), joten tietoa säilörehun apilapitoisuudesta voidaan käyttää esimerkiksi lehmille annettavan väkirehuannoksen suuruuden valintaan

Apilapitoisuuden määrittäminen botaanisella analyysillä on työlästä ja muilla menetelmillä kuten silmämääräisesti arvioiden varsin epätarkkaa. Puna-apilan kalsiumin (Ca) pitoisuus on huomattavasti korkeampi kuin nurmiheinien. Tämän tutkimuksen tarkoituksena oli selvittää, pystytäänkö nurmikasvuston puna-apilapitoisuus arvioimaan nurminäytteen Ca-pitoisuuden perusteella.

\section{Aineisto ja menetelmät}

Puna-apilan (lajikkeet Betty ja Bjursele) ja nurmiheinien (timotei ja ruokonata) seoskasvustoja seurattiin MTT:n tutkimuspaikoilla Juvalla ja Sotkamossa vuosina 2004-2006. Lohkot olivat luomuviljelyssä (Sotkamossa vuonna 2004 siirtymävaiheessa). Kaikilta käytetyiltä nurmiruuduilta (16 kpl) otettiin maanäytteet muokkauskerroksesta tutkimuksen alkaessa ja niistä määritettiin Ca-pitoisuus viljavuusanalyysin mukaan. Nurmikasvustoista otettiin näytteitä Haldrup-nurmenkorjuukoneella ensimmäisessä ja toisessa niitossa. Yhteensä näytteitä kerättiin $40 \mathrm{kpl}$. Nurminäytteiden puna-apilapitoisuus määritettiin erottelemalla kasvilajit käsin ja kuivaamalla ne yön yli $60{ }^{\circ} \mathrm{C}: \mathrm{ssa}$, jolloin apilan osuus voitiin ilmoittaa näytteen kuiva-aineessa. Alkuperäistä seoskasvustoa edustaneet näytteet kuivattiin myös, jauhettiin ja niiden Ca-pitoisuus määritettiin Valio Oy:n laboratoriossa XRF-menetelmällä (X-ray fluorescence). Samalla näytteistä määritettiin myös fosforin (P) ja kaliumin (K) pitoisuudet. Näytteiden kalsiumpitoisuuden ja puna-apilan osuuden yhteyttä tarkasteltiin regressioanalyysillä (SAS proc REG).

\section{Tulokset ja niiden tarkastelu Kalsiumpitoisuuden käyttäminen apilapitoisuuden ennustamisessa}

Taulukossa 1 on yhteenveto käytetystä näyteaineistosta. Apilan osuus kasvuston kuiva-aineessa oli 2. sadossa suurempi kuin 1. sadossa kuten tyypillistä. Ca-pitoisuuden vaihtelu oli varsin suurta, koska apilapitoisuuskin vaihteli. Rehutaulukoiden (MTT 2006) mukaan apilasäilörehun Ca-pitoisuus on keskimäärin 14 g/kg KA. Nurmiheinien 1. sadon Ca-pitoisuus Rehutaulukoiden mukaan on 1. sadossa 3.8 ja 2. sadossa 4.2 g/kg KA. Erot kasvilajien Ca-pitoisuudessa johtuvat eroista soluseinän rakenteessa. 
Apilan soluseinään sitoutuu runsaasti Ca:ta. Myös muiden palkokasvien Ca-pitoisuus on nurmiheiniä korkeampi. Tuorin ym. (2006) aineistossa puna-apilan Ca-pitoisuus oli keskimäärin 14.7, sinimailasen 15.5, keltamaitteen 11.8 ja vuohenherneen $9.0 \mathrm{~g} / \mathrm{kg} \mathrm{KA}$.

Rehutaulukoiden pitoisuuksia ja tämän aineiston apilan osuuksia käyttäen 1. sadon Capitoisuudeksi tulisi 7.5 g/kg KA ja 2. sadon 9.6 g/kg KA. Pitoisuudet, erityisesti 2. sadossa, ovat pienempiä kuin tästä aineistosta määritetyt. Maanäyteiden Ca-pitoisuudet olivat viljavuuslukissa 'huononlainen' - 'tyydyttävä' (Viljavuuspalvelu 2000), joten korkeampia pitoisuuksia ei voi selittää maan korkeilla Ca-pitoisuuksilla.

Fosforin ja kaliumin pitoisuudet ovat rehutaulukoiden mukaan hieman pienemmät apilapitoisessa rehussa nurmiheiniin verrattuna: P 2.3 ja 2.9 g/kg KA; K 26.3 ja 28.1 g/kg KA. P- ja K-pitoisuudet tässä aineistossa olivat matalampia kuin Rehutaulukoiden arvot. Tämä voi johtua siitä, että käytimme luomunurmia ja kasveille käyttökelpoisten kivennäisaineiden määrä maassa on voinut olla niukka.

Taulukko 1. Aineisto koostui MTT:n toimipaikoissa Juvalla $(n=21)$ ja Sotkamossa $(n=19)$ vuosina 2004-2006 kasvaneista apilapitoisista luomunurmista.

\begin{tabular}{lcccccccccc}
\hline & \multicolumn{4}{c}{ 1. sato $(\mathrm{n}=22)$} & & & \multicolumn{3}{c}{ 2. sato $(\mathrm{n}=18)$} \\
\cline { 2 - 3 } & $\begin{array}{c}\text { Keski- } \\
\text { arvo }\end{array}$ & $\begin{array}{c}\text { Keski- } \\
\text { hajonta }\end{array}$ & Min & Max & & $\begin{array}{c}\text { Keski- } \\
\text { arvo }\end{array}$ & $\begin{array}{c}\text { Keski- } \\
\text { hajonta }\end{array}$ & Min & Max \\
\hline Apila (\% KA:ssa) & 36.2 & 23.86 & 1.5 & 74.5 & & 55.2 & 18.95 & 17.0 & 80.4 \\
Maan Ca-pit. (mg/l) & 923 & 458.1 & 378 & 1893 & & 1007 & 540.9 & 378 & 1893 \\
Ca (g/kg KA) & 8.7 & 4.14 & 3.1 & 16.8 & & 14.6 & 3.99 & 8.4 & 20.5 \\
P (g/kg KA) & 2.0 & 0.30 & 1.5 & 2.6 & & 2.3 & 0.42 & 1.6 & 3.0 \\
K (g/kg KA) & 18.1 & 4.19 & 9.4 & 26.7 & & 17.4 & 6.62 & 7.6 & 26.8 \\
\hline
\end{tabular}

Kuvassa 1 koko aineiston apilapitoisuus on esitetty suhteessa näytteen Ca-pitoisuuteen. Yhteys on varsin selkeä, mikä näkyy myös taulukossa 2 esitetyissä regressioyhtälöissä. Yksinkertaisin yhtälö, jossa on mukana vain Ca-pitoisuus, toimi varsin hyvin. Selitysaste oli 0.800 ja mallin jäännösvaihtelu $10.7 \%$. Taulukossa 3 on havainnollistettu yhtälön käyttöä. Ca-pitoisuuden yhteys apilan osuuteen näyttää silmämääräisesti hieman käyräviivaiselta (kuva 1). Ca-pitoisuuden 2. asteen termi ei kuitenkaan ollut merkitsevä, paitsi kun myös maan Ca-pitoisuus oli mallissa mukana (taulukko 2).

Sadon (1 vs. 2. sato) huomioiminen paransi ennustetarkkuutta. Myös maan Ca-pitoisuudella oli merkitsevä vaikutus. Jos nämä lähtötiedot ovat käytettävissä, niiden hyödyntäminen on suositeltavaa. Artturi-verkkopalvelun (Artturi 2007) Laskurit-sivulla on käytettävissä laskuri, johon voi tallentaa näytteen lähtötiedot. Laskuri tulostaa apilapitoisuuden annettujen lähtötietojen perusteella. Tulosta voi edelleen käyttää kasvuston sitoman biologisen typen määrän arvioimiseen (Nykänen 2007) tai säilörehun syöntipotentiaalin määrittämiseen (Rinne ym. 2008).

Kuvasta 1 näkyy, että apilan osuus kasvustoissa oli Sotkamossa suurempi kuin Juvalla. Kasvupaikalla ei kuitenkaan ollut merkitsevää vaikutusta Ca-pitoisuuden ja apilan osuuden yhetyteen.

Apilapitoisuuden määrittämiseen on käytettävissä myös muita menetelmiä. Periaate on se, että muita menetelmiä verrataan botaaniseen analyysiin, jossa pellolta kerätystä näytteestä erotellaan käsin eri kasvilajit ja niiden osuudet punnitaan. Myös tähän menetelmään liittyy virhettä. Kasvilajit eivät jakaudu tasaisesti pellolla, joten riittävän kattavaan näytteenottoon pellolla ja pellolta kerätystä näytteestä lajitteluun tulevan osanäytteen edustavaan ottoon on kiinnitettävä suurta huomiota.

Suomessa on selvitetty apiloiden kevätlaskentaa ja ns. Rod Point -menetelmää, mutta niiden tulokset eivät olleet kovin rohkaisevia (Nykänen 2007). Apilapitoisuus on mahdollista määrittää myös suoraan NIR-menetelmällä (lähi-infrapunaspektroskopia), kunhan laite on kalibroitu riittävän laajalla ja kattavalla aineistolla (Nykänen ym. 2006). USA:ssa käytetään nurminäytteen ADF/NDF-suhdetta, joka on apilassa nurmiheiniä suurempi (ADF on happodetergenttikuitu ja NDF neutraalidetergenttikuitu). Suomessa ADF ei kuulu rutiinianalytiikkaan, joten sen tekeminen vain apilapitoisuuden arvioimiseksi ei ole perusteltua. Myös sulamattoman kuidun suhde kuituun (iNDF/NDF) on apilalla selvästi nurmiheiniä suurempi. 
Nurminäytteen Ca-pitoisuus määritetään Artturi-rehuanalyysin suppeassa kivennäisanalyysissä (Artturi 2007) ja rehujen kivennäispitoisuudet ovat hyödyllisiä tietoja myös eläinten ruokinnan suunnittelussa, mikä puoltaa Ca-pitoisuuden käyttöä myös apilapitoisuuden arviointiin. Tämän tarkastelun perusteella yhteys vaikuttaa niin selvältä, että lähestymistapa on toimiva. Aineisto on kuitenkin pieni ja sisältää vain luomunurmista kerättyjä näytteitä. Muut tiedot mm. kasvuston kehitysvaiheesta (D-arvo) ja kemiallisesta koostumuksesta saattaisivat parantaa ennustetarkkuutta. Kasvun edetessä kivennäisaineiden pitoisuudet tyypillisesti pienenevät nurmikasvustossa. Esimerkiksi Tuorin ym. (2006) aineistossa puna-apilan Ca-pitoisuus pieneni $0.11 \mathrm{~g} / \mathrm{kg}$ KA päivässä kasvun edetessä 1 . sadossa. Rehutaulukoiden (MTT 2006) mukaan Ca-pitoisuus apilasäilörehussa laskee kasvun edetessä 16:sta 12:en g/kg kuiva-ainetta (KA).

Ca- ja apilapitoisuuksien yhteys määritettiin nurmikasvustosta kerätyistä ja kuivatuista näytteistä. Menetelmää voi käyttää myös säilörehunäytteiden apilapitoisuuden arvioimiseen, koska Capitoisuudessa ei ole odotettavissa muutoksia säilönnän aikana.

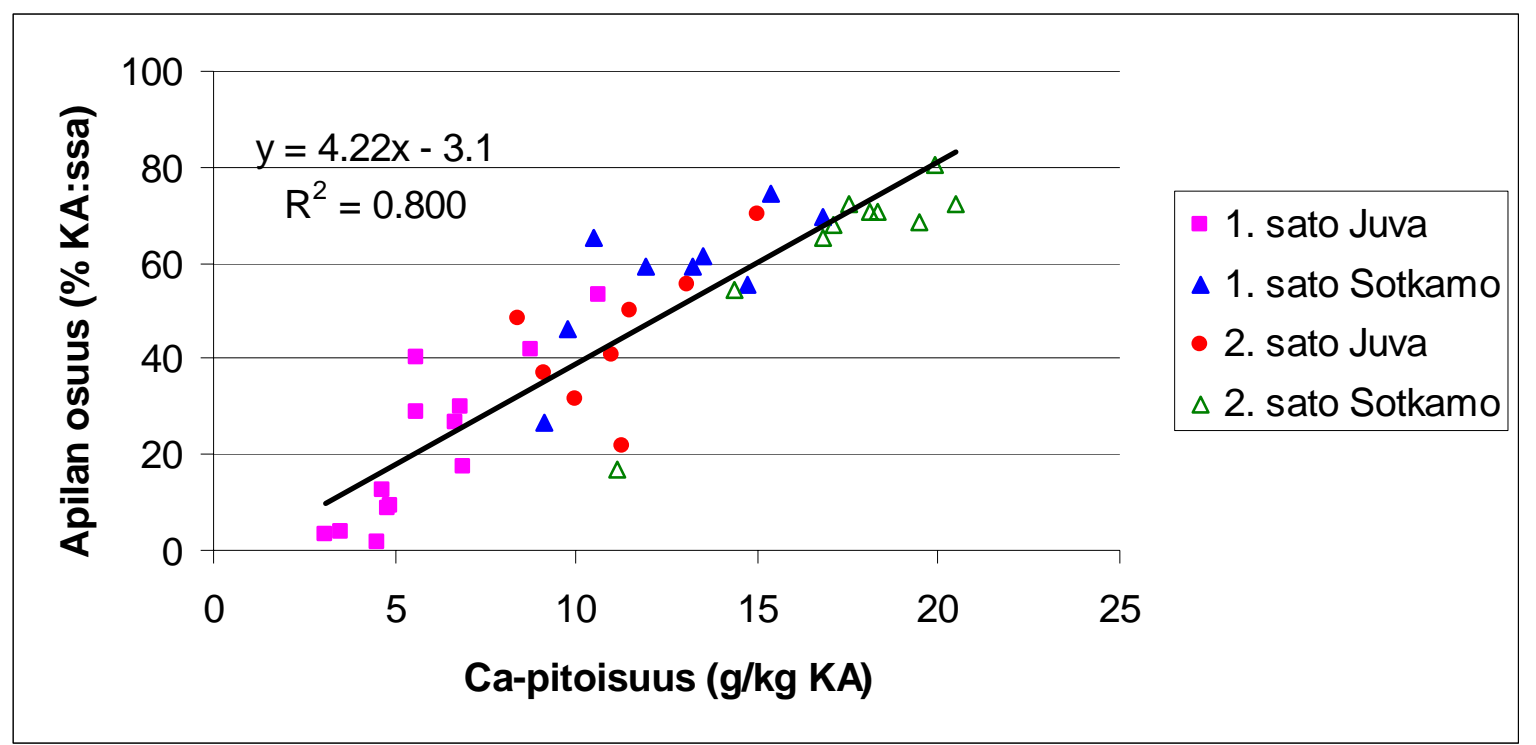

Kuva 1. Nurminäytteen kalsiumin (Ca) pitoisuuden ja puna-apilan osuuden yhteys oli selkeä ( $\mathrm{n}=40$ ). Kuvaan on merkitty erikseen Juvalla ja Sotkamossa kasvaneet 1. ja 2. sadon näytteet.

Taulukko 2. Nurmikasvuston apilapitoisuuden (\%) ennustaminen regressioyhtälöillä. Tilastollisesti merkitsevät $(\mathrm{P}<0.05)$ kulmakertoimet on lihavoitu.

\begin{tabular}{llccccccc}
\hline $\mathrm{X} 1$ & $\mathrm{X} 2$ & $\mathrm{X} 3$ & Vakio & $\mathrm{X} 1$ & $\mathrm{X} 2$ & $\mathrm{X} 3$ & Virhe $^{1)}$ & $\mathrm{R}^{2}$ \\
\hline $\mathrm{Ca}$ & & & -3.1 & $\mathbf{4 . 2 2}$ & & & 10.7 & 0.800 \\
$\mathrm{Ca}$ (1. sato) & & & -10.1 & $\mathbf{5 . 3 1}$ & & & 9.4 & 0.851 \\
$\mathrm{Ca}$ (2. sato) & & & -3.5 & $\mathbf{4 . 0 0}$ & & & 10.5 & 0.710 \\
$\mathrm{Ca}$ & Sato & & 3.7 & $\mathbf{4 . 7 5}$ & $\mathbf{- 8 . 9 1}$ & & 10.2 & 0.824 \\
$\mathrm{Ca}$ & $\mathrm{Ca}^{2}$ & & -18.4 & $\mathbf{7 . 4 1}$ & -0.137 & & 10.3 & 0.819 \\
$\mathrm{Ca}$ & $\mathrm{Ca}^{2}$ & Sato & -11.9 & $\mathbf{8 . 1 0}$ & $\mathbf{- 0 . 1 4 3}$ & $\mathbf{- 9 . 2 1}$ & 9.7 & 0.844 \\
$\mathrm{Ca}$ & Paikka & & -3.2 & $\mathbf{4 . 2 0}$ & 0.236 & & 10.8 & 0.800 \\
$\mathrm{Ca}$ & MaaCa & & -0.2 & $\mathbf{4 . 6 6}$ & $\mathbf{- 0 . 0 0 8}$ & & 10.2 & 0.822 \\
$\mathrm{Ca}$ & Sato & MaaCa & 11.8 & $\mathbf{5 . 7 1}$ & $\mathbf{- 1 3 . 4}$ & $\mathbf{- 0 . 0 1 2 9}$ & 8.9 & 0.869 \\
\hline
\end{tabular}

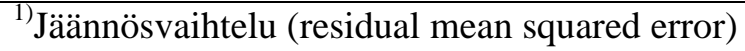

$\mathrm{Ca}=$ Nurminäytteen kalsiumpitoisuus (g/kg KA); $\mathrm{Ca}^{2}=\mathrm{Ca} \times \mathrm{Ca}$ (Ca-pit. käyräviivainen vaikutus)

Sato $=1$. sato vs. 2. sato

Paikka $=$ Nurminäytteiden kasvupaikkakunta (Juva vs. Sotkamo)

MaaCa = Maanäytteen Ca-pitoisuus (mg/l) 
Taulukko 3. Regressioyhtälön käyttäminen nurmen apilapitoisuuden laskemiseen näytteen Ca-pitoisuudesta.

\begin{tabular}{ccccccc}
\hline Vakio & & $\begin{array}{c}\text { Kulma- } \\
\text { kerroin }\end{array}$ & & $\begin{array}{c}\text { Ca-pitoisuus } \\
\text { (g/kg KA) }\end{array}$ & & $\begin{array}{c}\text { Apilan osuus } \\
\text { (\% KA:ssa) }\end{array}$ \\
\hline-3.1 & + & 4.22 & $\times$ & 4 & $=$ & 14 \\
-3.1 & + & 4.22 & $\times$ & 8 & $=$ & 31 \\
-3.1 & + & 4.22 & $\times$ & 12 & $=$ & 48 \\
-3.1 & + & 4.22 & $\times$ & 16 & $=$ & 64 \\
-3.1 & + & 4.22 & $\times$ & 20 & $=$ & 81 \\
\hline
\end{tabular}

\section{Apilapitoisuuden määrittäminen tilaolosuhteissa}

Apilapitoisuuden arviointi Ca-pitoisuutta käyttäen antaa tuloksen jälkikäteen, kun nurmesta on otettu näyte ja analysoitu se laboratoriossa. Korjuuaikaa päätettäessä tietoa kasvuston apilapitoisuudesta tarvittaisiin välittömästi "pellon pientareella”.

Apilapitoisuutta voi arvioida silmämääräisesti kasvustossa kulkien. Silmällä arvioiden apiloiden osuus näyttää helposti suuremmalta kuin se todellisuudessa on, koska apilat ovat kasvutavaltaan heiniä rehevämpiä ja lehtevämpiä. Omaa näkemystä ja kokemusta voi harjoittaa arvioimalla kasvuston apilapitoisuus ensin silmämääräisesti ja vertaamalla tulosta Ca-pitoisuuden avulla märitettyyn osuuteen tai tekemällä kasvilajimäärityksen itse. Näin voi kehittää omaa taitoaan silmämääräisen arvion tarkkuudessa.. Artturi-verkkopalvelussa on käytettävissä valokuvia kasvustoista, joissa apilan osuus on määritetty. Myös niiden avulla voi kehittää omaa nurmikasvuston apilapitoisuuden arviointikykyään (ks. https://portal.mtt.fi/portal/page/portal/Artturi/Korjuuaikatiedotus/Apilanurmen_analyysitulokset).
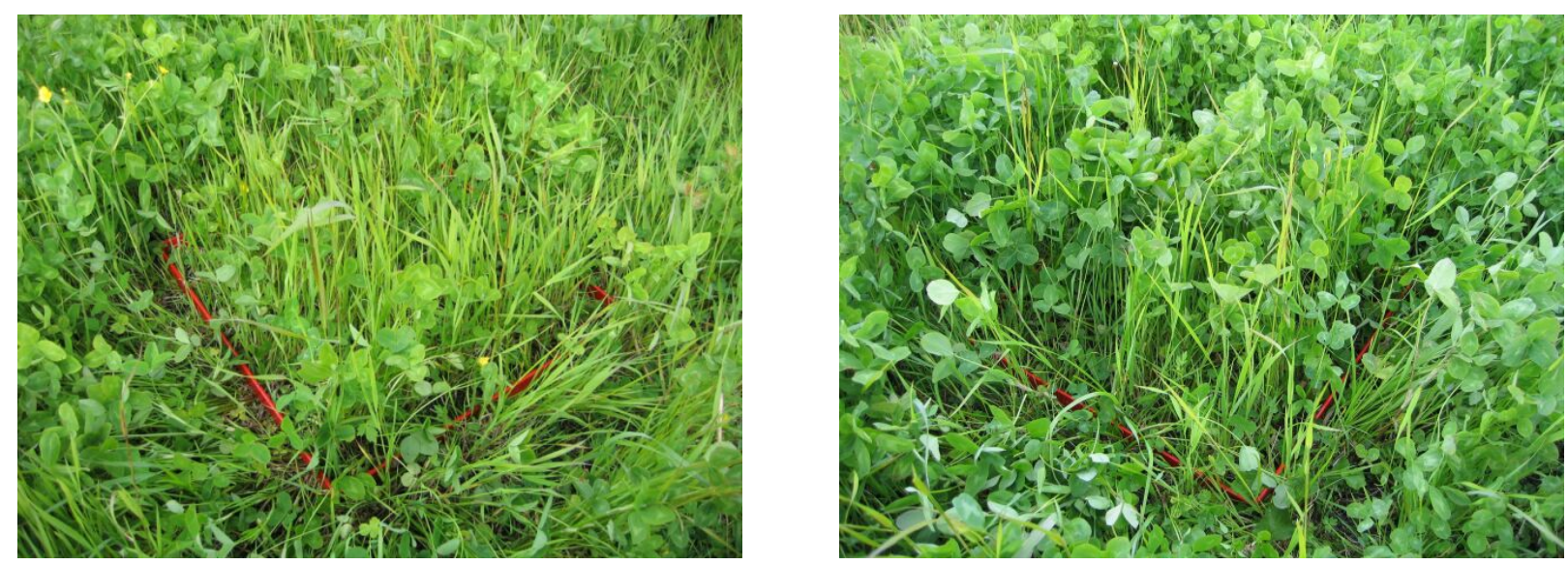

Kuva 2. Vasemmanpuoleisessa kuvassa kasvuston apilapitoisuus oli $33 \%$ ja oikeanpuoleisessa $75 \%$ kuiva-aineessa. Kuvat: Arja Nykänen.

Kasvustoja arvioitaessa peltoja on kierrettävä varsin tiheästi, sillä apilapitoisuus voi vaihdella huomattavasti lohkon eri osissa. Arvio pitäisi tehdä noin 80 metrin välein, jos haluaa edustavan arvion (Nykänen ja Jauhiainen 2007).

Apilapitoisuuden voi määrittää myös itse keräämällä pellolta seoskasvustoa. Näyte lajitellaan apilaan ja heiniin, jonka jälkeen molemmat kasvilajit punnitaan. Tulokseen vaikuttaa vielä kasvilajien ero kuiva-ainepitoisuudessa. Koska vedellä ei ole rehun arvoa, täytyy kasvilajiosuudet ilmaista osuutena kuiva-aineesta. Kasvien kuiva-ainepitoisuuden voi määrittää kotikonstein mikroaaltouunissa (työohje löytyy mm. Artturi-verkkopalvelusta), mutta kohtuullisen tarkkaan tulokseen pääsee myös kertomalla palkokasvin painon sen kuiva-ainepitoisuuden osuudella nurmiheinien kuiva- 
ainepitoisuudesta. Tämä luku on keskimäärin puna- ja alsikeapiloilla $66 \%$, valkoapilalla $55 \%$ ja mailasilla ja vuohenherneellä 90\% (Nykänen ja Rinne 2007). Laskentaa on havainnollistettu taulukossa 4.

Apilan ja nurmiheinien kuiva-aineen suhde on keskimäärin hieman matalampi kesän ensimmäisessä sadossa kuin jälkisadossa (0.61 vs. 0.75$)$. Sen sijaan suhde ei näytä kovin selkeästi muuttuvan kasvun edetessä. Karkeana ohjeena voidaan pitää, että seoksena kasvaneen luomuapilanurmen apilan kuiva-ainepitoisuus on $0.66 \times$ heinän kuiva-ainepitoisuus (aineistona Rinne ym. 2007). Kerroin voi olla hieman suurempi tavanomaisesti viljellyissä nurmissa, koska typpilannoitus pienentää nurmiheinien KA-pitoisuutta.

Koska apilan osuus vaihtelee huomattavasti, on kiinnitettävä erityistä huomiota siihen, että näyte kuvaa kattavasti kasvustoa. Jos näytteen ottaa määräalalta käyttäen esimerkiksi $50 \mathrm{~cm} \times 50 \mathrm{~cm}$ kehikkoa, jonka pinta-ala on siis $0.25 \mathrm{~m}^{2}$, voi näytteen punnitsemalla arvioida myös kasvuston hehtaarisadon. Taulukossa 5 on esitetty hehtaarisadon laskeminen määrä-alalta otettujen nurminäytteiden perusteella.

Taulukko 4. Puna-apilan pienemmän kuiva-ainepitoisuuden vaikutus apilan osuuden eroon tuoreessa näytteessä ja kuiva-aineessa. Esimerkissä on kerätty 2 kg nurminäytettä, joka on eroteltu apilaan ja nurmiheiniin. Apilan osuus kuiva-aineessa on laskettu kaavalla: suhde $\times$ apilan tuorepaino / [heinän tuorepaino + (suhde $\times$ apilan tuorepaino)].

\begin{tabular}{lcccc}
\hline Suhde $^{1)}$ & $\begin{array}{c}\text { Apilan tuore- } \\
\text { paino }(\mathrm{kg})\end{array}$ & $\begin{array}{c}\text { Heinän tuore- } \\
\text { paino }(\mathrm{kg})\end{array}$ & $\begin{array}{c}\text { Apilan osuus } \\
\text { tuoreessa }(\%)\end{array}$ & $\begin{array}{c}\text { Apilan osuus kui- } \\
\text { va-aineessa (\%) }\end{array}$ \\
\hline 0.66 & 0.50 & 1.50 & 25 & 18 \\
0.66 & 1.00 & 1.00 & 50 & 40 \\
0.66 & 1.50 & 0.50 & 75 & 66 \\
$0.61^{2)}$ & 1.00 & 1.00 & 50 & 38 \\
$0.75^{3)}$ & 1.00 & 1.00 & 50 & 43
\end{tabular}

${ }^{1)}$ Apilan kuiva-ainepitoisuus suhteessa samassa seoskasvustossa kasvaneiden nurmiheinien kuivaainepitoisuuteen

${ }^{2)} 1$.sato

${ }^{3)}$ 2.sato

Taulukko 5. Hehtaarisadon laskeminen määräalalta otetun näytteen perusteella.

\begin{tabular}{ccccc}
\hline $\begin{array}{c}\text { Näytteen } \\
\text { paino, } \mathrm{kg}\end{array}$ & $\begin{array}{c}\text { Näytteenotto- } \\
\text { ala, } \mathrm{m}^{2}\end{array}$ & $\begin{array}{c}\text { Tuoresato, } \\
\mathrm{kg} / \mathrm{ha}\end{array}$ & $\begin{array}{c}\text { Kuiva-aine- } \\
\text { pitoisuus, } \%\end{array}$ & $\begin{array}{c}\text { Kuiva-ainesato, } \\
\mathrm{kg} / \mathrm{ha}\end{array}$ \\
\hline Paino & Ala & Tuoresato & KA & \\
Punnittu & Mitattu & =Paino/Ala $\times 10000$ & Määritetty & $=$ Tuoresato $\times$ KA $/ 100$ \\
\hline 1.00 & 1 & 10000 & 25 & 2500 \\
2.00 & 1 & 20000 & 25 & 5000 \\
2.00 & 1 & 20000 & 50 & 10000 \\
2.00 & 2 & 10000 & 50 & 5000 \\
\hline
\end{tabular}

\section{Johtopäätökset}

Kalsiumpitoisuuden käyttäminen apilapitoisuuden arvioinnissa vaikuttaa lupaavalta menetelmältä, jolla on selkeitä käytännön sovellusmahdollisuuksia. Kalsiumpitoisuuden perusteella punaapilapitoisuuden voi laskea tässä julkaisussa esitetyllä kaavalla. Sadon (1. sato tai 2. sato) huomioiminen paransi ennustustarkkuutta jonkun verran, joten eri sadoille voi käyttää erillisiä kaavoja. Artturiverkkopalvelussa on käytettävissä laskuri, johon nurminäytteen kalsiumpitoisuuden voi tallentaa ja vastauksena tulostuu näytteen arvioitu puna-apilapitoisuus. Käytetty aineisto oli kohtuullisen suppea ja sisälsi ainoastaan luomunurmia, joten aineiston laajentaminen parantaisi todennäköisesti ennustustarkkuutta. 


\section{Kirjallisuus}

Artturi. 2007. Artturi -verkkopalvelu. Viitattu 30.11.2007. www.mtt.fi/artturi.

Hakala, K. \& Yli-Mattila, T. 2007. Vanhat ja uudet konstit apilanviljelyn menestykseen. Puna-apilaa nurmiin ja ruokintapöydälle. Puna-apila tehokkaasti luomumaidoksi -tutkimushankkeen päätösseminaari 17.4.2007. Toim. A. Vanhatalo \& M. Topi-Hulmi Suomen Nurmiyhdistyksen julkaisuja 25: 23-33.

https://portal.mtt.fi/portal/page/portal/AGRONET/HTML/NURMIYHDISTYS/sisallysluettelot/hakala.pdf

Mela, T. 2003. Red clover grown a in mixture with grasses: yield, persistence and dynamics of quality characteristics. Agricultural and Food Science 12: 195-212.

MTT, 2006. Rehutaulukot ja ruokintasuositukset -verkkopalvelu. Viitattu 30.11.2007.

www.agronet.fi/rehutaulukot

Nykänen, A. 2007. Määritä nurmen apilapitoisuus ja typen sidonta tilallasi. Puna-apilaa nurmiin ja ruokintapöydälle. Puna-apila tehokkaasti luomumaidoksi -tutkimushankkeen päätösseminaari 17.4.2007. Toim. A. Vanhatalo \& M. Topi-Hulmi Suomen Nurmiyhdistyksen julkaisuja 25: 23-33.

https://portal.mtt.fi/portal/page/portal/AGRONET/HTML/NURMIYHDISTYS/sisallysluettelot/nykanen2.pdf

Nykänen, A., Granstedt, A., Laine, A. \& Kunttu, S. 2000. Yields and clover contents of leys of different ages in organic farming in Finland. Biological agriculture \& horticulture 18: 55-66.

Nykänen, A., Jauhianen, L. \& Palojärvi, A. 2007 Kuinka maaperä vaikuttaa puna-apilanurmen kasvuun? Puna-apilaa nurmiin ja ruokintapöydälle. Puna-apila tehokkaasti luomumaidoksi -tutkimushankkeen päätösseminaari 17.4.2007. Toim. A. Vanhatalo \& M. Topi-Hulmi Suomen Nurmiyhdistyksen julkaisuja 25: 5-10. Saatavilla Internetissä:

https://portal.mtt.fi/portal/page/portal/AGRONET/HTML/NURMIYHDISTYS/sisallysluettelot/nykanen1.pdf Nykänen, A., Kurri, O., Kemppainen, J. 2006. Seosnurmen apilapitoisuuden määritys NIRS-analysaattorilla kuivatusta näytteestä. Toim. A. Hopponen. Maataloustieteen Päivät 2006, 11.-12.1.2006 Viikki, Helsinki [: esitelmät ja posterit]. Suomen maataloustieteellisen seuran tiedote 21: 4 p. http://www.smts.fi/pos06/1104.pdf Nykänen, A. \& Rinne, M. 2007. Palkokasveilla joustoa nurmen korjuuaikaan. Luomu 5/07, s. 8-10.

Pursiainen, P., Rinne, M., Hakala, K., Nykänen, A. \& Vanhatalo, A. 2007. Hyödyllinen puna-apila antaa haastetta. Maito ja Me 3/2007, p. 40-41.

Rinne, M., Nykänen, A., Nyholm, L., Nousiainen, J. \& Vanhatalo, A. 2007. Kehitysrytmi huomioitava apilanurmen korjuussa. Puna-apilaa nurmiin ja ruokintapöydälle. Puna-apila tehokkaasti luomumaidoksi tutkimushankkeen päätösseminaari 17.4.2007. Toim. A. Vanhatalo \& M. Topi-Hulmi Suomen Nurmiyhdistyksen julkaisuja 25: 23-33.

https://portal.mtt.fi/portal/page/portal/AGRONET/HTML/NURMIYHDISTYS/sisallysluettelot/rinne.pdf

Rinne, M., Huhtanen P. \& Nousiainen, J. 2008. Säilörehun ja koko rehuannoksen syönti-indeksit auttavat lypsylehmien ruokinnan suunnittelussa. Maataloustieteen Päivät 2008.

Tuori, M., Kuoppala, K., Pursiainen, P. \& Munck, M. 2006. Korjuuajan vaikutus nurmipalkokasvien kivennäispitoisuuteen. Toim. A. Hopponen. Maataloustieteen Päivät 2006, 11.-12.1.2006 Viikki, Helsinki [:esitelmät ja posterit]. Suomen maataloustieteellisen seuran tiedote 21: 7 p. http://www.smts.fi/pos06/1107.pdf Julkaistu 9.1.2006.

Viljavuuspalvelu 2000. Viljavuustutkimuksen tulkinta peltoviljelyssä. 31 s. Mikkeli. 